Currículo sem Fronteiras, v. 21, n. 1, p. 398-428, jan./abr. 2021

\title{
DIDÁTICA E EXPERIMENTAÇÕES NOS MODOS DE ENSINAR ${ }^{1}$
}

\author{
Marisa Vorraber Costa \\ Universidade Federal do Rio Grande do Sul - UFRGS \\ Viviane Castro Camozzato \\ Universidade Estadual do Rio Grande do Sul - Uergs
}

\begin{abstract}
Resumo
O mote central deste ensaio é problematizar o lugar da didática no ensinar, assim como revisar e atualizar suas concepções. A partir de uma breve introdução acerca das movimentações teóricas sobre educação, pedagogia e didática são apresentados relatos das trajetórias de duas professoras pesquisadoras, com menção a experimentações que abrangem o período 1971-2020. Tendo como eixo central a didática, questões relevantes da educação e da pedagogia são discutidas. Em tal incursão, são evidenciados os múltiplos contornos desse campo de saberes que vem, há décadas, sendo objeto de acalorados debates, especialmente no Movimento A Didática em Questão. Considerando seu entrelaçamento a condições sociopolíticas e culturais específicas, assim como a tendências teórico-conceituais emergentes em distintos contextos históricos, expõe-se, agora face às tensas circunstâncias de uma pandemia, o entendimento crescente de que a "arte de ensinar" lida com o inesperado, com a experimentação e com a criação.
\end{abstract}

Palavras-chave: Didática; Pedagogia; Ensino; Formação de professores.

\begin{abstract}
The central motto of this essay is to problematize the place of didactics in teaching, as well as reviewing and updating its conceptions. Based on a brief introduction about theoretical movimentations on education, pedagogy and didactics, reports on the trajectories of two researchers teachers are presented, with mention to experiments covering the 1971-2020 period. With didactics as the central axis, relevant issues on education and pedagogy are discussed. In such an incursion, the multiple contours of this field of knowledge that has been the subject of heated debates for decades are highlighted, especially in the Movement Didactics in Question. Considering its intertwining with specific socio-political and cultural conditions, as well as with theoretical and conceptual trends emerging in different historical contexts, it is exposed, now in face of the tense circumstances of a pandemic, the growing understanding that the "art of teaching" deals with the unexpected, with experimentation and with creation.
\end{abstract}

Keywords: Didactics; Pedagogy; Teaching; Teacher training. 


\section{Introdução}

As preocupações e movimentações acerca das maneiras como se pensa e opera incisivamente na educação das pessoas remontam aos séculos XVI e XVII, raiar da era moderna. Os mundos antigo e medieval levaram a efeito modos muito próprios de educação, de que são exemplos a paidéia grega e, com a revolução cristã, uma cultura escolar organizada sobre saberes da fé, da esperança e da caridade ensinados através de textos religiosos. A tradição pedagógica da qual somos herdeiros hoje, enraizada nas que a antecederam, expressa uma vocação inequívoca para o governo minucioso dos indivíduos e da vida social.

Os contornos do mundo moderno delineiam-se em um longo período de instabilidades em busca de caminhos para emergir da plêiade de dogmas e do hermetismo de uma sociedade religiosa estática e autoritária que se interpunha à constituição de uma visão de mundo e de humanidade mais aberta (CAMBI, 1999). É nesse panorama que intelectuais e educadores europeus como Peter Ramus e Juan Vives, entre outros, e depois deles especialmente Jan Amos Comenius, intentaram imprimir um novo ordenamento à educação, particularmente àquela dirigida a crianças e jovens. Comenius é reconhecido como o educador que instaurou, em um alentado conjunto de textos, os dispositivos fundantes das relações educativas escolares, difundidos amplamente pelo mundo ao longo dos últimos quatrocentos anos. Sua obra monumental, aquela que, segundo Narodowski (2001), ao mesmo tempo honra e expressa a origem do pensamento moderno, é a Didática Magna, "[...] obra fundante, completa e totalizante" (p. 14), conhecida como o grau zero da pedagogia moderna.

À trilha aberta por esses pedagogos agregaram-se outros pensadores, ao longo dos séculos posteriores, suscitando entendimentos e desenvolvendo teorias, análises e propostas de educação nas quais, em meio a continuidades, descontinuidades e rupturas, persistiu a preocupação com os modos de ensinar. Nesse percurso, segundo os ideais pedagógicos de cada época, foram sendo incorporadas reflexões provenientes de vários campos de saber e diversificadas matrizes de pensamento, contudo, o foco na escola e na sala de aula nos parece nunca ter sido perdido de vista. Tal perspectiva se justificaria, a nosso ver, e em certa medida, pela sempre renovada queixa acerca do distanciamento entre teoria e prática, isto é, entre o que afirmam e propõem as teorias educacionais e educativas ${ }^{2}$ e aquilo que tem sido possível efetivamente realizar na materialidade dos espaços escolares, como voltaremos a tratar posteriormente.

Consideramos instigante referir, neste ponto, as movimentações entre educação, pedagogia e didática já no nosso tempo. São diversas as acepções em torno desses conceitos, e iniciamos com as que abordam a educação. Nos meados do século XX, constitui-se um conjunto de disciplinas que tinha como pretensão lidar com os fatos educativos em seus níveis macro e micro, carregando consigo a vontade de transformar a educação em ciência. Inevitável aqui pensarmos sobre os efeitos de saber-poder implicados na pletora de processos para produzir as ciências da educação, dentre eles, a fragmentação do ensino a partir de especializações que passaram a lidar, cada vez mais profundamente, 
com parcelas do processo educativo, como são os casos da Psicologia da Educação, da Filosofia da Educação, da História da Educação, da Sociologia da Educação, assim como da Administração Educacional, entre outras.

Importa destacar, primeiramente, as ambições "[...] de poder que a pretensão de ser uma ciência traz consigo", como nos indica Foucault (1999, p. 15). Associam-se a esse ponto os tipos de saber e os sujeitos que, consequentemente, passam por processos de desqualificação e, do mesmo modo, em quais tipos de saber, de sujeitos e áreas de conhecimento se pretende injetar efeitos de poder ao nomeá-los como científicos.

Nesse cenário, temos cada área especializada da educação incumbida de construir o conjunto de teorias que embasariam a pedagogia. Autores como Fabre (2004) asseveram que no processo de especialização da educação — com a centralidade das ciências da educação - a pedagogia foi relegada à prática e, portanto, conhecimento subserviente às ciências da educação. Suas especificidades foram, em parte, apagadas. Considerada dessa forma "simples prática", a pedagogia ficou refém das ciências da educação que assumiram intensas movimentações para liderarem um processo de legitimação de seus discursos. Caberia às ciências da educação, assim, fornecer elementos para se pensar os processos pedagógicos desde as esferas da Sociologia, Filosofia, Psicologia, Administração, etc. Desse modo, "A multiplicação das ciências humanas vem acompanhada pela vontade de cada uma inserir a educação em seu próprio campo.” (HOUSSAYE, 2004, p. 18).

Com a Sociologia da Educação ficariam, por exemplo, os debates em torno das questões sociais que afligem a instituição escola e seus sujeitos; com a Filosofia da Educação, as reflexões em torno dos processos e sistemas educativos; com a Psicologia da Educação, o foco no ensino-aprendizagem a partir da Psicologia do Desenvolvimento e de um olhar para a escola como organização e assim por diante.

Para nós, diferentemente disso, a pedagogia é tanto um saber quanto uma prática; tanto teoria quanto fazer articulados. Tal entendimento implica o questionamento de qualquer cisão entre teoria e prática. A pedagogia analisa, inquire, perscruta, indaga e cria a partir de análises sobre processos educacionais específicos. Autores como Luzuriaga (1961), Planchard (1962), Cambi (1999), dentre outros, já evidenciaram os inúmeros embates em torno da pedagogia que incluem desde uma conceituação como arte, filosofia, técnica, etc., mas sobretudo tentativas de legitimação para ser compreendida como uma ciência. Entretanto, ao nos movimentarmos nesse campo, seguimos colocando em questão as pretensões em torno desse tipo de tentativa de tornar, nesse caso, a pedagogia uma ciência.

Poderíamos reafirmar, no rastro de Fabre (2004), Houssaye (2004), mas também de Zuluaga et al. (2011a), que a pedagogia envolve tanto um saber — o saber pedagógico quanto uma prática - a prática pedagógica. Zuluaga et al. (2011a, p. 15) ressaltam que "[...] a adoção do termo saber para a pedagogia busca que qualquer investigador da educação se situe no conhecimento como se estivesse em um espaço aberto", a partir do qual, sobretudo, "[...] possa se deslocar e se orientar, desde as regiões mais sistematizadas

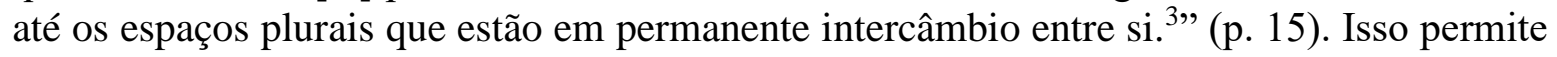
que a pedagogia possa ser vista e analisada a partir de contextos espaço-temporais específicos, estando aberta para as trocas e mutações decorrentes desses espaços plurais. A 
pedagogia, sob esse ponto de vista, não está associada a qualquer pretensão totalizante advinda dos investimentos para torná-la ciência, mas sim, relacionada à noção de saber "[...] que permite estabelecer pontes, caminhos e encontros com outros saberes e ainda com disciplinas formalmente constituídas" (p. 16).

Emerge desse entendimento do saber pedagógico como aberto à pluralidade o conceito de didática como "[...] o conjunto de conhecimentos referentes a ensinar e aprender que conformam um saber." (ZULUAGA et al., 2011b, p. 38). Mais especificamente, e tendo relação com os processos de invenção das ciências da educação, a didática diz respeito aos diferentes modos pelos quais - a partir de um saber específico - se vai formular o processo de ensino-aprendizagem. Ou seja, "A didática é o discurso através do qual o saber pedagógico pensou o ensino até fazê-lo o objeto central de suas elaborações. Através da história, a didática não tem cessado de abrir seu discurso a conceitos e métodos sobre o ensino." (p. 37).

O objeto de estudo da Didática ${ }^{4}$, nessa linha de pensamento, é o ensino, considerado, sobretudo, a partir de condições sociais específicas. Por isso mesmo, a didática não se restringe a um conjunto de técnicas prescritivas, uma vez que elas sempre serão provisórias e amparadas em situações muito concretas e não passíveis de generalização. Ainda que resquícios da ambição comeniana de "ensinar tudo a todos" possam ser ainda perceptíveis, o ensino é prática social que se transforma continuamente. Devido a isso, "[...] a didática na atualidade acolhe a discussão que questiona um único método de ensino e se orienta em direção à diferenciação de métodos para os saberes particulares" (ZULUAGA et al., 2011b, p. 39). A "arte de ensinar" - expressão que deriva da palavra Didática que, em grego, é nomeada como techné didaktiké: ou seja, arte ou técnica de ensinar —, assim, tem sido compreendida como provisória, aberta, plural.

Face à importância da escola, as restrições decorrentes de condições de múltiplas naturezas que se interpõem ao ensino redundaram, ao longo dos tempos, em tentativas de superá-las. Talvez a mais recorrente delas tenha sido a inscrita no paradigma pedagógico denominado tecnicista, que circunscreveu o problema do ensino ao interior da escola e considerou as técnicas didáticas como a solução para o aprimoramento das formas de trabalho nas salas de aula. Na esteira dessa concepção, o saber didático assumiu centralidade nos meados do século XX, distanciado, a nosso ver, da preocupação com atitudes e valores que marcou as origens da pedagogia moderna, mas herdeiro da mesma vontade de coordenar as ações e governar a vida de crianças e jovens das escolas e universidades.

Outros movimentos em torno dos modos de ensinar entraram em pauta em países de diferentes continentes ao longo de décadas mais recentes, remexendo a cena pedagógica e alimentando renovados debates acerca da educação e da pedagogia em um mundo que se torna cada vez mais distinto daquele de outros tempos. Além disso, inesperadamente, neste início da terceira década do século XXI, uma pandemia ${ }^{5}$, com raros precedentes na história da humanidade, interditou repentinamente o acesso às escolas e direcionou mais de um bilhão de estudantes do planeta ao ensino via telas de computadores e smartphones, agora circunscritos ao espaço doméstico. Inicialmente considerada uma alternativa de curto prazo 
e passageira, tal modalidade já evidencia saturação de suas estratégias improvisadas e suscita um movimentado, amplo e tenso debate acerca dos modos de ensinar mediados pelas tecnologias que se multiplicam e aperfeiçoam constantemente. Reafirma-se, assim, a concepção de ensino como prática social que se reinventa e se recompõe continuamente. Nela, as discussões sobre didática voltam a ocupar lugar destacado, agora na cena pedagógica de uma nova era na qual os aparatos tecnológicos digitais assumem um protagonismo sem precedentes ${ }^{6}$.

Em meio a tal panorama, este artigo consiste em um ensaio a quatro mãos, que articula as trajetórias acadêmicas de duas professoras pesquisadoras, tendo como eixo as relações com o trabalho do ensino, especialmente com a didática, tornada componente curricular de cursos de formação de professores com os quais ambas estiveram e ainda estão envolvidas. O objetivo principal dessa incursão por nossas aproximações com esse campo de saberes e conhecimentos é, justamente, investir numa tentativa de mostrar como diferentes tempos, circunstâncias e condições foram produzindo distintas formas de conceber, praticar e ensinar didática. Pretendemos também evidenciar como um saber alçado à condição de disciplina acadêmica vai assumindo múltiplos contornos pressionado pelo poder operante e pelas urgências que este faz aflorar em cada tempo, em variadas geografias, conjunturas e contingências. Ao fazer isso, entram em pauta formas de pensar sobre as incontáveis e sempre renovadas invenções na arte de ensinar, a nosso ver, um foco ainda demasiadamente negligenciado quando se trata de formar professores hoje.

\section{Primeira Aproximação — anos 1971-2012 (professora Marisa Vorraber Costa)}

Ao organizar o pensamento para rever minhas relações com a didática e o ensino, tomei duas referências para um passeio no tempo. Por um lado, reportei-me aos desafios que enfrentei como professora e também como mestranda nas décadas cinzentas da ditadura militar, e nos muitos "desdobres" que isso exigiu de docentes afinados com um pensamento mais aberto e plural, como era o caso de muitos daqueles cuja licenciatura em Filosofia ocorrera em uma universidade pública ${ }^{7}$ brasileira nos anos 1960 , entre os quais me incluo. Boa parte de nossos professores havia realizado sua formação em universidades europeias ou norte-americanas e aportavam por aqui as experiências acadêmicas vivenciadas em seminários e grupos de estudo conduzidos por destacados filósofos. Foi uma época de grande ebulição intelectual e de desencaixes de todo tipo no campo do pensamento, marcados pela experiência filosófica do pós-estruturalismo que reverberou particularmente sobre as formas de ensinar e aprender. Período de muitos conflitos pelo mundo (como a guerra do Vietnã, a guerra fria, as guerras coloniais, a edificação do muro de Berlim), assim como de turbulentos e ruidosos movimentos contestatórios da juventude, entre eles os acontecimentos de maio de 1968 na França. Tempo também da revolução sexual, da feminista, dos costumes, assim como da angústia existencialista e tantos outros desencantos e desencontros que foram produzindo transformações profundas no panorama intelectual, 
científico, político e, como não poderia deixar de ser, também no panorama pedagógico do mundo contemporâneo pós-guerras. A experiência de Vincennes, na França, é um marco nesse sentido ${ }^{8}$.

Por outro lado, considerei as possibilidades vislumbradas a partir dos estudos do curso de doutorado ${ }^{9}$ em educação, realizado no início dos anos 1990, que resultaram na abertura de um imenso panorama de novas perspectivas de abordagem e pensamento, de reflexão e problematização, especialmente com minha aproximação aos Estudos Culturais em Educação inspirados na vertente de pensamento pós-estruturalista. Em expansão pelo mundo na década de 1980, e identificados como uma pós-disciplina por seu caráter articulador de saberes de vários campos, os Estudos Culturais abriram caminhos para um amplo repertório de novas e variadas questões a serem formuladas no que se poderia agora denominar de "outros territórios da educação".

Lanço mão, aqui, de uma retrospectiva que eu havia esboçado quando, em novembro de 2012, participei de uma Mesa Redonda ${ }^{10}$ assinalando os 30 anos do Movimento $A$ Didática em Questão (1982-2012), do qual eu fizera parte ativamente como professora de Didática e Prática de Ensino ${ }^{11}$ a partir de meados dos anos 1980. Fazer jus à honra do convite para aquele evento significou, para mim, uma reaproximação com o campo temático da didática, elemento significativo de minha trajetória profissional. Além disso, como integrei aquela Mesa junto com a idealizadora do Movimento, professora Vera Maria Candau $^{12}$, e com a professora Zaia Brandão, ambas do Programa de Pós-Graduação em Educação da PUC-RIO, sendo eu a única participante externa ao Rio de Janeiro, considerei que isso expressava certo reconhecimento às contribuições dos Estudos Culturais - minha área de atuação e pesquisa - para uma reviravolta no pensamento sobre educação e ensino no Brasil ${ }^{13}$.

Preparei-me muito para aquela participação ${ }^{14}$, visando compor uma abordagem minimamente informada sobre algumas questões implicadas nas discussões sobre didática ao longo de trinta e poucos anos. Pretendi também refletir sobre as transformações nas concepções de educação, pedagogia e didática e, particularmente, sobre o que aprendi na Didática, sobre didática e com a didática em mais de 40 anos de exercício do magistério em todos os níveis de ensino. Assim, expus naquele evento as reflexões ensejadas ao revisitar minha trajetória como professora, como formadora de professores, como pesquisadora e formadora de pesquisadores, o que me ajudou a enxergar como se constituíra aquilo que penso hoje sobre muitos temas e questões da educação e do ensino. Quais experiências, vivências, urgências, alegrias, sucessos, frustrações, decepções, desencaixes e embates foram delineando minhas formas não só de pensar, mas também de atuar em cada um desses lugares. Relato a seguir algumas etapas que considero significativas nesse longo processo de modelagem de minhas formas de atuar como professora e pensar sobre elas. 


\section{Eu... professora de escolas, professora de faculdade, mestranda...}

“As aulas foram uma parte da minha vida, eu as dei com paixão. [...] É preciso muito tempo de preparação para obter alguns minutos de inspiração." (DELEUZE, Conversações, 1992, p. 173)

Iniciei minha atuação como professora em 1971, imediatamente após concluir a Licenciatura em Filosofia ${ }^{15}$, em plena ditadura militar, lecionando a recém-criada disciplina de Educação Moral e Cívica (EMC) nos cursos ginasial e colegial de um Colégio de Aplicação $^{16}$ (CA). A EMC integrou a Divisão de Filosofia do colégio, de forma que os vínculos com a Filosofia e seus professores contribuíram para que meu plano de ensino pudesse escapar um pouco do forte acento ideológico que caracterizava a introdução desse novo componente curricular. Não foi nada fácil, contudo, iniciar a vida de professora planejando e ensinando uma disciplina instituída para ser mais um sustentáculo do autoritarismo, e na qual tudo que se pensasse, discutisse e ensinasse estava sujeito a vigilância e risco.

Neste mesmo ano de 1971, face ao gradativo banimento da Filosofia dos currículos da maioria das escolas, decidi cursar a Habilitação em Supervisão Escolar ${ }^{17}$ (na época com duração de 2 anos após a licenciatura), no curso de Pedagogia, visando criar alguma perspectiva de trabalho no, à época em implantação, Ensino de $1^{\circ}$ e $2^{\circ}$ Graus.

No ano seguinte, em 1972, por indicação de colegas e ex-professoras, passei a lecionar Psicologia da Educação ${ }^{18}$ em duas escolas para jovens do sexo feminino ${ }^{19}$, e Filosofia nas turmas do $2^{\circ}$ Grau de um Colégio Lassalista misto - Colégio São João - uma vez que algumas escolas confessionais ainda mantinham a disciplina no currículo. Nesse colégio Lassalista, em seguida, fui direcionada a atuar também como coordenadora pedagógica face à implantação da Reforma de Ensino regulada pela Lei 5.692/71. Especialmente a implantação das habilitações profissionais no ensino de $2^{\circ}$ grau movimentava todas as escolas do País e requeria conhecimentos técnico-pedagógicos especializados, que eu adquiria cursando a Habilitação em Supervisão Escolar.

Foi um período em que a reverberação do patrulhamento político na vida cotidiana, somado à insegurança em relação ao campo de trabalho na educação, iam forjando comportamentos adaptativos de sobrevivência. Foram as dificuldades iniciais para dar conta de turmas numerosas, compostas de jovens adolescentes que precisávamos manter atentos e acomodados dentro da sala de aula, obedecendo rigorosamente sua duração regulamentar, sem barulho e sem discussões "impróprias", que me instigaram a buscar ajuda em métodos e técnicas didáticas supostamente recomendáveis.

O que recordo ainda vivamente é que consegui encarar tais dificuldades lançando mão de estudos dirigidos, técnica didática que havia aprendido nas disciplinas da formação pedagógica — Psicologia e Didática — do curso de licenciatura, estas ministradas na Faculdade de Educaçãa ${ }^{20}$. Tentei também empregar técnicas de dinâmica de grupo $\left(G_{V G O}{ }^{21}\right.$, Tempestade Cerebral ${ }^{22}$, Cochicho ${ }^{23}$ e outras), assim como técnicas de trabalho individual (Instrução Programada e outras) ${ }^{24}$. Todas elas, porém, mostravam-se de difícil 
operacionalização nas salas de aula, assim como algumas exigiam um imenso trabalho de preparação em casa e surtiam pouco efeito em termos de interesse e disciplina dos estudantes. Com o passar do tempo, fui aprendendo a fazer adaptações e a mesclar vários tipos de atividades de forma a manter meus alunos interessados e ocupados em sala de aula. Logo aprendi que manter os alunos ocupados o tempo todo era a "alma do meu negócio". Qualquer tempo livre durante as aulas ensejava situações que escapavam do meu controle, especialmente por eu ser ainda inexperiente e bem jovem face a meus alunos e alunas do $2^{\circ}$ grau. E nada como muitas tarefas, com materiais para examinar, ler e escrever, para manter todos trabalhando constantemente e, assim, permanecerem sempre me "devendo" alguma tarefa. A técnica do Estudo Dirigido me parecia adequada exatamente porque eu podia montar um para uma ou duas semanas de aula, incluindo nele variados tipos de atividades, que eu planejava com antecedência, em casa, nos finais de semana. Cheguei a adquirir um mimeógrafo a álcool para preparar o material diariamente. Quer dizer, tanto os alunos quanto a professora eram coordenados pelas técnicas didáticas.

Em 1972, uma das minhas ex-professoras - Mérion Campos Bordas ${ }^{25}$ — convidoume a atuar como docente nos cursos de formação de coordenadores pedagógicos para as escolas polivalentes do PREMEN ${ }^{26}$. Nesses cursos, ensinei teorias de ensino (Ausubel, Brunner, Gagné, Rogers) e trabalhei com treinamento em microensino para o desenvolvimento das habilidades técnicas de ensino. Tal experiência era oriunda da Universidade de Stanford, com várias formas de adaptação/execução em universidades brasileiras nos anos setenta. No Rio Grande do Sul, foi desenvolvida com base no livro de Flávia Maria Santana, intitulado Microensino e habilidades técnicas do professor, em conjunção com a obra Taxionomia de objetivos educacionais, de Benjamin S. Bloom, um clássico na formação de professores da época. A modalidade microensino compreendia as etapas ensino-feedback-reensino, que treinávamos em microaulas de cinco ou dez minutos cada uma. Nelas, o objetivo era desenvolver [e treinar mesmo!] as habilidades técnicas de organizar o contexto, formular perguntas, ilustrar com exemplos, providenciar feedback e promover a avaliação. Aprendi muito, nesse tempo, sobre "a arte de ensinar". E por mais que se falasse em "habilidades técnicas", eu já começava a perceber que outras capacidades e outras habilidades, que não apenas as técnicas, atravessavam as práticas docentes e promoviam as condições que ajudavam a ensinar melhor naquele tempo tão singular.

Em 1973, em pleno regime militar ditatorial no País, ingressei no Mestrado em Educação $^{27}$, sendo então convidada por outra ex-professora a integrar a equipe que lecionava a disciplina de Estrutura e Funcionamento do Ensino de $1^{\circ}$ e $2^{\circ}$ graus no Curso de Pedagogia da mesma universidade. Esta, mais uma disciplina introduzida nos currículos por força da Reforma de Ensino implantada com a Lei 5.692/71, que imprimia acento técnico profissionalizante ao ensino fundamental e médio, na época sob a nova denominação de Ensino de $1^{\circ}$ e de $2^{\circ}$ Graus. Mais uma vez, foram as turmas imensas do Curso de Pedagogia (em torno de 60 alunos) e a quantidade de turmas (duas ou três em cada semestre do curso), que fizeram a equipe de professoras ${ }^{28}$ preocupar-se muito com os modos de ensinar, levando-nos a organizar um Manual Didático-Pedagógico ${ }^{29}$ que oferecia tanto textos, gráficos e trechos de documentos legais para leitura, como variados exercícios para 
feedback e "fixação dos conteúdos". As aulas eram quase invariavelmente introduzidas por uma exposição-dialogada, seguida por exercícios e outras atividades propostas no Manual a serem realizadas pelas alunas do Curso. O uso daquele Manual se disseminou pelo País e foi corrente em inúmeros cursos de Pedagogia dessa e de outras universidades brasileiras nos anos que se seguiram. Era praticamente o único material didático que subsidiava o trabalho em sala de aula sobre a nova legislação educacional (Lei 5.692/71 e correspondentes pareceres e resoluções emanados dos conselhos de educação).

Ao longo daqueles anos da década de 1970, minhas preocupações com o trabalho didático em sala de aula foram constantes. $\mathrm{O}$ acento tecnicista imprimido à educação formal e ao processo de ensinar e aprender foi notável, contribuindo, a meu ver, para o objetivo de deslocar o foco de atenção dos significados e da reflexão para a forma. Em um tempo de grande efervescência de novas ideias e teorias no mundo, mantivemo-nos delas apartados, amedrontados pelas práticas autoritárias de uma ditadura que se mostrava cada vez mais cruel com seus críticos e com a resistência.

Isso me levou, no Mestrado, a realizar um estudo sobre Preferências de alunos por Métodos de Ensino, sendo a dissertação defendida em 1980. Os resultados da pesquisa ${ }^{30}$ apontaram que a ampla maioria dos iniciantes preferia aulas expositivas, sendo que entre os concluintes diminuía um pouco essa tendência, apesar de persistir como majoritária, mas despontando preferência um pouco mais acentuada pelo trabalho em pequenos grupos. $\mathrm{O}$ trabalho individualizado despertava pouco interesse entre os alunos. Destaco que esse estudo suscitou muitas reflexões acerca do significado do professor na sala de aula como agente da educação, para além das técnicas didáticas.

No início dos anos oitenta, após a conclusão do mestrado, participei da criação de um setor didático-pedagógico ${ }^{31}$, onde, junto com algumas colegas, trabalhei na organização e funcionamento de um serviço voltado para o aprimoramento do ensino na universidade. Sua criação pretendia responder às demandas por melhoria da qualidade do ensino superior, acompanhando uma tendência verificada em muitas universidades brasileiras naquele período, públicas ou privadas. Tais iniciativas, em variadas modalidades, persistiram até anos mais recentes, com vistas a apoiar o pessoal docente que atua sem formação pedagógica na maioria dos cursos universitários. Foi um tempo em que o livro Fazer Universidade, de Cipriano Lucchesi, era uma bíblia a ser seguida. Estudava-se também Escola e Democracia, de Dermeval Saviani; Magistério de $1^{o}$ grau - Da competência Técnica ao compromisso político, de Guiomar Namo de Melo, dentre outros. Eram os alvores das teorias críticas da educação no Brasil.

Aquela experiência colocou-me face a face com a dimensão das dificuldades pedagógicas enfrentadas por professores de várias áreas acadêmicas que atuavam no ensino sem qualquer preparação para isso. Naqueles anos oitenta, quando começavam a ser formuladas e proclamadas publicamente as críticas ao tecnicismo, ao formalismo técnicopedagógico e à visão instrumental e pretensamente neutra da educação - compartilhadas pelas integrantes do referido setor - , a equipe, após inúmeras tentativas de realizar um trabalho mais compreensivo e interpretativo da ação pedagógica, capitulou e optou por introduzir (com pouco sucesso) o treinamento em microensino com pequenos grupos de 
professores, assessorando-os, paralelamente, no planejamento e organização das atividades das aulas.

O desconhecimento do campo pedagógico, de suas teorias, técnicas e práticas, por parte da grande maioria dos professores universitários, particularmente daqueles das áreas tecnocientíficas, conhecidas como "ciências duras", revelou-se uma barreira quase intransponível para a efetivação de um ensino que despertasse o interesse dos alunos pelas aulas.

Só nos meados dos anos 1980, prestei e fui aprovada em Concurso Público para ingresso em uma universidade pública ${ }^{32}$ como professora de Didática e Prática de Ensino. Esse foi um dos primeiros concursos de fato públicos a ocorrer na UFRGS após os vinte anos da ditadura militar. Na condição de professora de Didática Geral e de Prática de Ensino de Filosofia ocorreram minhas aproximações mais significativas com o campo da Didática como disciplina acadêmica, com suas questões, problemas e desafios.

Em uma época em que a Didática se debatia em busca de redefinições e caminhos que a configurassem curricularmente para além de um apêndice composto por orientações técnicas, mecânicas e tecnológicas, os estágios nos colocavam diante de situações de sala de aula que apontavam veementemente para a necessidade do domínio de competências técnicas pelo professor. Especialmente no caso do ensino de Filosofia, isso se fazia visível. Invariavelmente os estagiários aceitavam a licenciatura como uma "provação" a ser cumprida para depois chegarem a certo "paraíso" onde viveriam exclusivamente de especulações filosóficas. Praticamente todos declaravam, nas aulas de Prática de Ensino, que desejavam se tornar filósofos e não professores de Filosofia. Havia até uma brincadeira de que o destino vislumbrado pelos alunos dos cursos de Filosofia, no Brasil, naqueles anos, era o Galeão, numa alusão ao sonho de fazer mestrado no exterior, em universidades, à época, destacadas no campo da Filosofia por terem reconhecidos filósofos em seu corpo docente - Oxford e Cambridge, na Inglaterra; Stanford e Berkley, nos EUA; Sorbonne, na França, assim como universidades alemãs e austríacas, berços da teoria crítica, da filosofia analítica e de outras tendências renomadas do pensamento filosófico dos meados do século XX. Anos depois da colação de grau desses alunos, eu encontrava alguns, e lá estavam eles atuando como professores de Filosofia; "temporariamente", reafirmavam, mas com algum constrangimento.

Na disciplina de Didática Geral daquele tempo (1985-1995), ensinávamos, em minha análise de hoje, uma didática muito descaracterizada. Planejamento de ensino e avaliação, dentre outros tópicos, era algo negligenciado no programa da disciplina de Didática, voltado centralmente para temas e discussões de cunho mais analítico e crítico. Era uma tentativa, a meu ver, de contemplar as questões sociopolíticas que, nas décadas da ditadura militar, estiveram ausentes do campo da educação e da pedagogia no Brasil. Tive que batalhar por alterações na distribuição da carga horária da Prática de Ensino de Filosofia para realizar um trabalho de mais longo prazo (dois semestres). Isso me permitiu, então, desenvolver discussões de fundo para se pensar o ensino de Filosofia no conjunto dos saberes curriculares que, ao longo daqueles anos, formavam os jovens do ensino médio, 
assim como para projetar as estratégias didático-pedagógicas apropriadas a um trabalho mais reflexivo com os conteúdos filosóficos selecionados.

Hoje penso que, ao se exacerbar a crítica a uma visão instrumental da educação e de disciplinas correspondentes do campo, abarrotou-se a carga horária de Didática com conteúdos e textos de variados matizes, especialmente de sociologia, filosofia e política, relegando-se ao segundo plano as vinculações da didática com a pedagogia. Ao fazer isso, houve um distanciamento das discussões pedagógicas cruciais que conectam os modos de ensinar com seu tempo e, mais do que isso, com as estratégias para formar sujeitos para um projeto de sociedade.

De fato, as políticas educacionais passavam por revisões e se mantinham eivadas de ambiguidades, o que instalava as áreas de formação docente em um território pantanoso com ventos soprando em múltiplas direções. O próprio Movimento A Didática em Questão, ao fazer uma crítica ao acento metodológico da didática comeniana, não atentava para o contexto histórico que a instituíra e negligenciava seus pressupostos voltados à formação de pessoas para organizar, produzir, criar e viver em certo tipo de sociedade.

A meu ver, ao atribuir-se pouca relevância ao estudo de Comenius (Didática Magna, 1625, séc. XVII), nos afastávamos das possibilidades de análise de uma das formas mais competentes já inventadas para educar sujeitos encaixados na racionalidade que orienta/sustenta um projeto de sociedade. "Ensinar tudo a todos", o ideal pansófico de Comenius, já alertava que nada poderia ficar de fora, assim sendo, estratégias de ensinar não são neutras e também são cruciais e afinadas com políticas culturais e políticas de Estado. O que inúmeros estudos nos têm mostrado, hoje, é que pedagogias proliferaram em todos os territórios da vida contemporânea, expressando uma "vontade de pedagogia"33 vigorosa, disseminada e sem precedentes, que modela sujeitos para os mais variados e inclusive, alguns, abomináveis, desígnios que se possam imaginar.

Só hoje percebo que praticamente substituir, na disciplina de Didática, questões de métodos e técnicas por aquelas da Sociologia e da Filosofia indicava certo despreparo do campo da educação para vislumbrar a imbricação entre questões sociais, políticas, culturais e filosóficas com opções pedagógicas, metodológicas e didáticas. Advém daí, talvez, a importância da abertura para novos horizontes instaurada com os Estudos Culturais em Educação, que promovem múltiplas e variadas articulações entre campos disciplinares distintos.

Hoje considero que o Movimento A Didática em Questão (que surge com o fim da ditadura militar) não estava isolado das demais movimentações que atravessaram as sociedades (ocidentais, mas não apenas essas!) a partir dos anos sessenta. Expressavam uma impaciência histórica com os resíduos ainda resistentes de uma era e de um projeto de mundo assentado sobre clareza, limpeza e ordem, e que se pensava como melhor, mais evoluído, mais esclarecido que todos os demais.

As movimentações no campo da Didática foram consentâneas, a meu ver, com essa "sintomatologia" mais ou menos disseminada. Ademais, elas expressaram, em meio a esse "estado da cultura", um inconformismo com os encaminhamentos sociopolíticos em nosso 
país, procurando arregimentar certa resistência, no campo da educação, ao modelo de sociedade e de racionalidade política vigentes.

Contudo, relendo alguns textos produzidos no Movimento A Didática em Questão, me parece ter havido uma dispersão de esforços. Dispersão que aconteceu no entremeio das tentativas de superação de uma didática instrumental - esta com inequívocos indícios de seu comprometimento com um projeto político ditatorial, elitista e excludente - e a “invenção de outra didática". Esta, agora, caracterizada como didática crítica, em busca da didática fundamental — aquela que entenderia as dimensões política e técnica como interligadas e interdependentes (tal como foi pensada por Vera Maria Candau, Magda Becker Soares, e outros, no livro Rumo a uma nova didática, organizado por Candau em 1988). Pensava-se uma didática situada historicamente e identificada com os anseios por uma educação voltada para a maioria da população brasileira, até então escanteada nos projetos político-sociais daquele tempo. E, por isso mesmo, uma educação que para ser efetiva não poderia dispensar a competência técnica, o saber fazer bem feito. Algo que, a meu ver, até hoje se persegue, mas ainda com pouco sucesso.

De qualquer forma, embora com objetivos claramente formulados, o Movimento era manifestação de um tempo de crise da Didática. Havia encaminhamentos em variadas direções e o tecnicismo ainda mantinha algum vigor. Tempos de crise são também tempos de dispersão. Dispersão que se vislumbra dentro do próprio Movimento A Didática em Questão (congressos em 1982, 1983, 1985), que tem continuidade com os ENDIPEs ${ }^{34}$ (a partir de 1987).

Por um lado, havia uma tensão relativamente à pertinência dos estudos de Comenius e Dewey (escola tradicional e escola nova), depois resgatados em trabalho de Gasparin (1994) e também de Cunha (1994). Por outro, havia os impasses atribuídos à carência de "evidências empíricas", de dados sobre as práticas no dia a dia escolar, que deveriam ser coletados em estudos que investigassem os cursos que formavam professores, suas salas de aula, assim como as salas de aula das escolas. Isso desencadeou inúmeras pesquisas sobre currículos, planos e programas de ensino em cursos de formação de professores ${ }^{35}$. Havia ainda as novas propostas que surgiam como alternativas - como a "pedagogia críticosocial dos conteúdos", de José Carlos Libâneo, 1987; e a "didática-prática”, de Pura Lúcia Oliver Martins, 1989. A primeira, com grande repercussão, logo foi batizada de "conteudista" e atormentada por expressar, segundo alguns, um certo retrocesso tanto político quanto no que diz respeito às concepções de educação, currículo e pedagogia.

E persistia, dentre tantos encaminhamentos, a busca um tanto obsessiva pela especificidade da Didática, encaixando-a na esteira das movimentações em direção a um estatuto científico da educação e da pedagogia. Esse desejo de capturar a Didática e aprisioná-la em um campo próprio, a meu ver, não era consistente com uma motivação acionada pela urgência de escapar de respostas acabadas e inequívocas e abrir-se para um leque imprevisível de outras possibilidades e modos de pensar. A busca pela especificidade me parece ter caminhado na contramão daquilo que, talvez, tenha sido o moto desencadeador do Movimento A Didática em Questão. 


\section{Eu... doutora, pesquisadora e professora da Pedagogia...}

“[...] uma aula não tem como objetivo ser entendida totalmente... Uma aula é uma espécie de matéria em movimento... Por isso é que é musical..." (DELEUZE, $O$ abecedário ${ }^{36}$ )

No início de 1995, apresentei minha tese de doutorado ${ }^{37}$ - Gênero, classe $e$ profissionalismo no trabalho de professores e professoras de classes populares —, que aponta para dois elementos importantes: $1^{\circ}$ ) a reafirmação de minha constante preocupação com o trabalho do ensino, expressa agora na escolha do trabalho docente ${ }^{38}$ como foco de pesquisa; e $2^{\circ}$ ) a emergência de outras questões implicadas na docência, que pude vislumbrar com as lentes obtidas em uma literatura internacional que abria novas perspectivas para pensar. Destaco aqui: a) a tese de Antonio Nóvoa - Le Temps de professeur, de 1987 — sobre a emergência da profissão do ensino, com referencial foucaultiano; b) os estudos oriundos da Sociologia das Profissões, com destaque para o trabalho de Magali Sarfatti Larson - The rise of professionalism, de 1977 (também inspirado em Foucault); c) os estudos sobre trabalho docente de Martin Lawn, Jenny Ozga

e Gerald Grace ${ }^{39}$, até aquele momento pouco conhecidos e estudados no Brasil; e d) os estudos de gênero que ganhavam espaço em nosso País, especialmente com a chegada dos Estudos Culturais ao campo da Educação.

A partir da tese, comecei a trabalhar com outros referenciais, sendo que, particularmente, os estudos de gênero, os estudos foucaultianos e a perspectiva pósestruturalista de análise vincularam-me cada vez mais aos Estudos Culturais, de onde vieram a inspiração, as lentes e as ferramentas teóricas com as quais dei continuidade a meu trabalho de ensino e pesquisa até hoje.

Contudo, foi ao ingressar outra vez em uma universidade privada ${ }^{40}$ como docente, em 2002, que retornei às salas de aula da graduação como professora de Sociologia da Educação no Curso de Pedagogia. Foi aí que, novamente, confrontei-me com os desafios da pedagogia e da didática. Universidade particular, turmas numerosas, curso noturno e uma "clientela" composta por trabalhadoras de todo o tipo, que chegavam às salas de aula no início da noite, sem tempo para uma refeição adequada, e após uma extensa e pesada jornada de trabalho iniciada, não raro, às seis horas da manhã. Uma nova condição de existência e de trabalho no ensino descortinou-se para mim.

Dei-me conta de que a grande maioria das professoras e professores em nosso País estava sendo formada em cursos noturnos (ou à distância!), realizados depois de extensas jornadas diárias de trabalho, não raro sucedidas por deslocamentos em longas distâncias. Observei que quando o curso era presencial, frequentavam-no de forma mais ou menos irregular, permanecendo nas aulas o tempo estritamente necessário para captar meia dúzia de informações e orientações sobre tarefas, retornando às suas casas tarde da noite, a preparar-se para a jornada de trabalho do dia seguinte, igualzinha a essa que recém descrevi. Quando estudavam? Quando liam os textos? Quando preparavam tarefas para o 
curso de graduação que realizavam? Os relatos de alunas indicavam que, quando conseguiam fazer alguma dessas atividades, era nos finais de semana, quase sempre apenas no domingo (e nem em todos eles!), no tempo roubado à família, ao cônjuge, às tarefas domésticas e à vida pessoal. Onde e como estudavam? Em locais exíguos, em textos fotocopiados da pior qualidade (não dispunham de recursos financeiros para comprar livros, as bibliotecas eram pobres com acervos restritos ${ }^{41}$ e o acesso à internet dependia de aparatos tecnológicos nem sempre acessíveis), e, em geral, com a TV ligada para conter as crianças da família a sua volta, e o celular ativo para alertar sobre outras urgências. Quando iam ao cinema, ao teatro? Quando liam jornais ou revistas? Quando liam livros? Quando participavam de palestras, debates ou refletiam sobre o que liam? Quando visitavam algum museu? Praticamente nunca! Até aquele momento, eu jamais havia imaginado tais condições para professores e professoras brasileiros que buscam se qualificar.

Decidi "aterrisar" naquele universo e começar a disciplina perguntando a minhas alunas e raros alunos se saberiam me dizer o que é Sociologia. A resposta mais razoável e elaborada que obtive foi: "algo que tem a ver com a sociedade". Comecei por aí! Por que se estuda "algo que tem a ver com a sociedade" em um curso de Pedagogia? Percebi em seguida, também, que as lacunas relativas não só à falta de conhecimentos prévios ${ }^{42}$ e de familiaridade com a reflexão, mas também o restrito repertório vocabular, não me permitiriam ir muito longe sem uma boa "estratégia" de ensino, que fosse mais ou menos uma estratégia de luta contra todas aquelas limitações.

Foi então que inventei uma Sociologia da Educação que pudesse ser ensinada com filmes. De forma que eu não precisasse depender de uma discutível suposta capacidade de abstração e contasse o tempo todo com a materialidade das imagens, das histórias narradas nos filmes, dos seres humanos de carne e osso, de suas condições de vida, de suas práticas, dos modos de vida de cada tempo e lugar. Inspirei-me na conhecida argumentação de Humberto $\mathrm{Eco}^{43}$ sobre a riqueza explicativa das histórias — "aquilo sobre o que não se pode teorizar, deve ser narrado" 44 _, ao defender que as histórias são sempre mais ricas do que qualquer ideia. Precisei historicizar a Sociologia, para que não fosse um ensino vazio de sentido, produzindo anotações fortuitas nas páginas de alguns cadernos. Só depois, pude introduzir alguns de seus temas, conceitos e teorias.

Para isso, foi necessário contar um pouco das histórias do mundo e das "humanidades" que o habitam. De como os seres humanos, em uma longa trajetória histórica, passaram a ser vistos e nomeados, enfim, como cidadãos com direitos e deveres. Haveria algo melhor do que filmes? Começamos com $O$ nome da Rosa, passamos por muitos outros (entre eles, Lutero, Os Miseráveis, Cuore, Sarafina, Mentes perigosas, A excêntrica família de Antónia $)^{45}$ e encerramos a disciplina com Entre os muros da escola e Pro dia nascer feliz.

Ao finalizar o semestre, levavam consigo uma lista de filmes para que prosseguissem aprendendo - para além das aulas de Sociologia da Educação - com as magníficas lições que uma boa filmografia pode oferecer ${ }^{46}$. Foi preciso primeiro revisitar e reinterpretar fatos históricos para que pudessem compreender porque e como saberes como a economia e a política se tornaram ciência e, em seguida, que condições sociopolíticas e culturais permitiram/favoreceram/impuseram o nascimento da Sociologia. Só assim foi possível 
estudar "objetos da sociologia", entre eles, a educação, a escola, a família, a sociedade, o sujeito, o poder, o governo.

Posso afirmar com segurança que essa foi a experiência docente que mais exigiu de mim como professora. Para cada turma e a cada semestre, além de rever a seleção e sequência dos filmes, fui inventando outros modos de explorá-los nas aulas. Havia reação às cópias legendadas, pois a habilidade de leitura frequentemente era precária e a usual assistência a filmes dublados em canais abertos de TV parece que vai acomodando o espectador à condição de ouvinte e não de leitor, observador e, depois, escritor. Organizei também roteiros para assistir aos filmes, compostos de questões que demandavam atenção constante e anotações mesmo na semi-obscuridade da sala de aula transformada em sala de cinema. Para além da experiência estética de espectador, eu pretendia explorar o cinema em sua dimensão de documento histórico e informativo, assim como de narrativa, de textualidade que (re)inventa acontecimentos. Os filmes, mesmo os documentários e as tais "histórias verídicas", não são "a verdade verdadeira" sobre aqueles fatos, mas uma das incontáveis versões sobre eles. Depois de assistir aos filmes, debates em sala de aula e textos (curtos) lidos paralelamente completavam o quadro para as reflexões e análises sociológicas. Certamente ensinei História, Geografia e muitas outras matérias, e apenas um pouco de Sociologia. Mas como se ensina e aprende Sociologia sem situá-la em um lugar e em um tempo?

$\mathrm{E}$, assim, penso eu, se atualizam as questões formuladas pelo Movimento A Didática em Questão, pois as técnicas didáticas nunca são apenas técnicas! Os modos de ensinar e os formatos que assumem estão eivados de intencionalidades, desenham-se segundo certa racionalidade e procuram edificar formas de compreensão desejáveis.

A partir daqui, recorro às minhas conversas com a professora Viviane Castro Camozzato, pedagoga, doutora em educação, integrante de nosso grupo de pesquisa e docente no curso de Pedagogia de uma jovem universidade pública ${ }^{47}$. Sua formação deu-se trinta e poucos anos depois da minha, toda na educação pública brasileira, do $1^{\circ}$ grau (em uma escola de pequeno município interiorano) ao curso de Pedagogia, mestrado e doutorado em Educação ${ }^{48}$. Quando preparei aquela participação na Mesa Redonda sobre o Movimento A Didática em Questão, perguntei a ela se gostaria de me contar um pouco acerca da disciplina de Didática na universidade em que atuava já nesta segunda década do século XXI e se poderia comentar sobre o que considerava significativo para se pensar sobre os trinta anos do referido Movimento.

Ela então relatou que havia cruzado com a didática ao lecionar a disciplina de Metodologia do Ensino Médio ${ }^{49}$, no curso de Pedagogia, assim como no dia a dia de sua prática docente. Nessa disciplina, segundo ela, bem interessante, metade teórica e metade prática, sempre discutiam questões de didática. Os alunos frequentavam as aulas teóricas, mas também iam a campo, vivenciavam novamente as escolas de ensino fundamental, conversavam e interagiam com alunos e professores. Nesse movimento se deparavam com resistências de todo o tipo, mas aguçar o olhar sobre as práticas que acontecem lá nas escolas, sobre as renegociações diárias, resultava bem atraente e enriquecedor para eles. Embora a discussão sobre teoria e prática fosse conhecida na área acadêmica, parece que, 
no cotidiano dos cursos de formação de professores, os alunos não compreendem tão facilmente suas inter-relações. Não é à toa que dentre as principais críticas ao curso de Pedagogia feita pelos estudantes de lá (e, recorda ela, também por seus colegas de curso de Pedagogia realizado na UFRGS décadas antes) surgia sempre a questão de que o curso é muito teórico, quase sem prática. Ou, nessa mesma direção, a ideia reafirmada incessantemente de que "na prática a teoria é outra", ou seja, procurando vincular teoria e prática quase como uma receita culinária que teria que dar certo de qualquer jeito, que, independentemente dos ingredientes, produzisse sempre o mesmo resultado.

Isso era algo que eu também percebia em minhas aulas na graduação em qualquer tempo. Ir para a prática parecia ser a pedra de toque dos cursos que formam professores! E eu insistia com os estudantes que sem boas teorias não se pratica nada interessante com potencial para vir a transformar a vida das pessoas. Sem teoria repetimos sempre o mesmo, não se descortinam novos panoramas, não se vislumbram outras possibilidades nem se formulam novas hipóteses. Naquelas ocasiões, eu costumava brincar invocando um enunciado: "um dia vocês vão concordar comigo que a teoria é a alma do nosso negócio!"

Pois bem, passados já mais de 30 anos do Movimento que remexeu e talvez continue a remexer as entranhas da Didática, observam-se algumas poucas mudanças significativas no panorama composto pelas dificuldades encontradas e pelas formas de pensar sobre elas, seja no que se refere às escolas como aos cursos que formam professores. Lentamente, contudo, parece que outras maneiras de abordar tais limitações, mediante a formulação de novas questões, sugerem indícios de que transformações estariam ocorrendo e outras formas de pensar e praticar didática estariam emergindo.

Daqui em diante, para entremear nossas experiências, a professora Viviane Castro Camozzato passará também a invocar passagens de sua trajetória, trazendo elementos para, na terceira parte deste texto, dedicarmo-nos a reflexões sobre focos que nos parecem significativos em um ensaio sobre as conexões entre uma ideia de didática, de educação, de pedagogia e a formação para atuar na "arte de ensinar" hoje.

\section{Segunda Aproximação - anos 2000-2020 (professora Viviane Castro Camozzato)}

Ao ser instigada a me manifestar sobre a didática na condição de professora de graduação em universidade pública, entremeando minhas experiências acadêmicas e profissionais, foi com inquietação que comecei a pensar sobre o lugar da didática em minha trajetória. Por um lado, vasculhei na memória os encontros com a didática no decorrer da minha formação e atuação docentes. De certo modo, percebi que a didática esteve quase que no "subterrâneo" da Pedagogia que cursei, enquanto que na atuação ela consiste em um de meus centros de interesse, na medida em que tornou possível, ao longo dos anos, uma constituição e um exercício como professora que considero mais "arejado".

No início dos anos 2000, período em que realizei a Licenciatura em Pedagogia, identificávamos uma cisão no curso: a metade inicial era, em grande parte, composta de 
discussões embasadas em autores ligados às teorias críticas ${ }^{50}$, enquanto que a final foi intensamente marcada pelas teorias pós-críticas ${ }^{51}$. Isso significa que, em um primeiro momento, éramos constituídas a partir de um engajamento da docência voltada à crítica e à transformação social. Mais adiante, temáticas associadas a políticas de identidade, análises culturais, pedagogias culturais, gênero, sexualidade, poder-saber, além de outras, eram introduzidas e esmiuçadas em diferentes componentes curriculares.

Vejo muitas aproximações possíveis entre as teorias críticas e pós-críticas, mas também identifico que, frente aos embates em torno dos "porquês" (por que um conhecimento e não outro? Por que o privilégio de determinados tipos de representações da docência e não outros? Por que...?) - característicos dessas teorias —, o "como fazer", associado às teorias tradicionais ${ }^{52}$, acabou sendo relegado a segundo plano. Devido a isso, a didática foi, em grande parte, negligenciada em meu processo formativo uma vez que, sobretudo, éramos convocadas a assumir um tipo de subjetividade docente mobilizada para a análise e a problematização social, sendo que os modos de ensinar pareciam não ter nada a ver com isso.

Vale destacar que no início dos anos 2000 havia uma efervescência em torno de debates acerca do multiculturalismo e dos direitos de grupos sociais diversos. Sentíamos os avanços das pautas sobre políticas de identidade e uma exaltação pela entrada desses debates nas políticas e práticas educacionais. Pouco mais de quinze anos após a assim chamada redemocratização do Brasil, parece que a educação brasileira perseguia uma necessária inclusão e reconhecimento de agendas que tentassem contemplar questões sociais urgentes, assim como incluir a prática da crítica social: seja a partir das teorias críticas e/ou pós-críticas.

Por outro lado, ao revisitar minha trajetória, procurei evidências de reverberações de alguns dos muitos fios discursivos que me constituíram como uma professora que almeja analisar cenários, realizar diagnósticos e planejar ações que tentem desencadear processos de ensinar e aprender. Nessa movimentação, ao mesmo tempo em que identifico um "esvaziamento" das discussões sobre didática na minha formação, percebo a abertura para cruzamentos e (re)invenções, associando a docência à criação. Creio que hoje compreendo que, talvez, aprender a problematizar constantemente também se configurava como certo ato didático. Ou seja, aprendíamos a colocar em suspensão as verdades construídas e a questionar qualquer pretensão a respostas unívocas e totalizantes. Isso mobilizava a um tipo de artesania em que a docência era atrelada a um estado permanente de efetuar a crítica (tanto em âmbito mais global quanto local). Mesmo assim, vale frisar que o esvaziamento da didática era tanto que nem o seu nome era comumente pronunciado e apenas após o início da minha atuação como professora universitária passei a considerá-la, de fato, como de muita relevância.

Reporto-me, a seguir, a alguns movimentos e deslocamentos que penso serem significativos para compor um pouco do cenário e do entendimento da arte de ensinar que tem me cercado e tornado uma professora e pesquisadora interessada nas articulações entre educação, pedagogia e didática. 


\section{Eu... professora de faculdade, doutora...}

"Pensar é sempre experimentar, não interpretar, mas experimentar, e a experimentação é sempre o atual, o nascente, o novo, o que está em vias de se fazer." (Deleuze, Conversações, 1992, p. 132)

Iniciei minha atuação como professora universitária em 2011, próximo à conclusão do meu Doutorado em Educação, ocorrido no ano seguinte. Aprovada em Concurso Público para uma universidade estadual, desloquei-me de Porto Alegre para o interior do estado para trabalhar na Licenciatura em Pedagogia. Carregava comigo as angústias em relação a "como ensinar", "quais estratégias utilizar", "de que modo atuar para que os estudantes construíssem conhecimentos". Além disso, me questionava em relação à formação pela qual passara por perceber que, ao mesmo tempo em que havia me propiciado acesso a discussões desalojadoras e instigantes, deixara certo silêncio no que concerne aos modos de ensinar.

Quais estratégias existem e quais utilizar? Por quê? Como não replicar as experiências de, exaustivamente, organizar as aulas em trabalhos em grupo? Será que mesclar aulas expositivo-dialogadas com métodos mais ativos seria uma possibilidade fecunda? De que modo criar estratégias de investigação da realidade escolar e docente para além da carga horária teórica? A cada aula havia a demanda de muitas horas de estudo, dedicação e organização pedagógica: era preciso investigar os conhecimentos prévios dos estudantes para ampliá-los, mas também criar contextos investigativos e análises de experiências pedagógicas, manter o rigor conceitual, bem como uma articulação entre os conhecimentos macro e micropolíticos, entre outras questões.

Nessa transição para a prática docente universitária senti necessidade de buscar estratégias, técnicas e práticas para ensinar. Eu precisava de noções que me dessem um direcionamento e uma abertura para conhecer e recriar a partir disso. Obras como A prática educativa: como ensinar (ZABALA, 1998), Competência pedagógica do professor universitário (MASETTO, 2003), Processos de Ensinagem na Universidade Pressupostos para as estratégias de trabalho em aula (ANASTASIOU e ALVES, 2004), Metodologia do Ensino Superior (GIL, 2005), A gestão da aula universitária na PUCRS (GRILLO et al., 2008), entre outros, foram estudadas por mim à exaustão. Durante os anos iniciais de minha atuação precisei adentrar nas questões didáticas, conhecer seus embates e autores para pensar a didática tanto no ensino superior quanto na educação infantil e nos anos iniciais do ensino fundamental por minha vinculação ao curso de Pedagogia.

Grande parte de minha movimentação inicial, desse modo, englobou pesquisar e conhecer materiais que continham possibilidades didáticas para experimentar na docência. Concomitantemente, questionava como após graduação, mestrado e doutorado na área da educação, tais discussões eram ignoradas por mim. A meu ver, tal desconhecimento era intenso, também, por ter tido uma formação na graduação com forte acento em uma quantidade limitada de estratégias didáticas (trabalhos em grupo, principalmente) e na pós- 
graduação com grande parte das aulas ministradas de forma expositiva e expositivadialogada. Ou seja, meu encontro com a didática era restrito pela falta de referenciais bibliográficos e de referenciais advindos da experiência vivida.

Comecei a perceber, então, que a didática praticamente foi relegada ao subterrâneo da minha formação, como comentado anteriormente. Ela foi um profundo silêncio em um período em que as preocupações em torno do porquê ensinar (das teorias críticas às póscríticas) foram tão acentuadas. Nesse jogo, a didática, provavelmente, era renegada por ser considerada uma parte da pedagogia excessivamente burocrática, prescritiva e instrumental e, talvez, por ainda carregar resquícios da rejeição ao tecnicismo. Ao mesmo tempo, quando as preocupações em torno da didática entraram em minha formação, o que ocorreu na metade final do curso de Pedagogia, foi em um período em que não conseguíamos construir muitas diferenciações entre a pedagogia, o currículo, a didática, a filosofia..., uma vez que as problematizações advindas das já mencionadas políticas de identidade, pedagogias culturais, questões étnicas, de gênero e sexualidade, transformações socioculturais, etc., eram centrais. Ou seja, quais seriam as especificidades da didática se as suas discussões eram atravessadas por temáticas que já vínhamos estudando em outros componentes curriculares, sobretudo a partir de um viés pós-crítico?

Assim, fui me desconstruindo e reinventando como professora frente às preocupações sobre como ensinar, de que modos dispor as aulas, como construir propostas em sala de aula que colocassem em jogo operações de pensamento complexas como comparar, observar, operar com hipóteses, imaginar, criticar, supor, analisar, decidir, entre outros (ANASTASIOU e ALVES, 2004). Se no início eu era uma professora universitária que tomava demais a palavra, elaborava muitas aulas expositivas e trabalhava extensivamente com leituras, aos poucos minha atuação foi sendo marcada pela ampliação de meu repertório de estratégias, técnicas e práticas didáticas. Ou seja, a cada planejamento, com cada turma, a didática passou a ser detalhadamente considerada e explicitada. Se em uma aula minhas estratégias continham momentos de tempestade cerebral, análise crítica de algum material e/ou tema e posterior debate, em outra aula estratégias distintas seriam acionadas para que os estudantes da Pedagogia trabalhassem tanto com variadas operações de pensamento quanto pudessem vivenciar um processo formativo a partir de múltiplas estratégias e encontros com a didática.

$\mathrm{Na}$ atuação docente com a Pedagogia, tenho investido em contextos investigativos, ateliês ${ }^{53}$ e na vivência direta dos estudantes para que uma ressignificação da função docente seja experimentada. Promovo a visita a exposições de arte, museus, participação em saraus, assistência a peças de teatro, bem como a ampliação do repertório cultural a partir da aproximação com artistas, todas elas aliadas a outras estratégias e recursos - como os trabalhos em grupo e as aulas expositivo-dialogadas inclusive. Tenho procurado valorizar, cada vez mais, um modo de olhar e organizar processos de ensinar e aprender que considerem cada sujeito como potente para ser protagonista nas movimentações em busca do conhecimento.

Observo, agora, o quanto o encontro com a didática no decorrer da minha prática docente tem produzido uma "reviravolta" na bagagem que eu tinha até o ingresso no Ensino 
Superior como professora. Experimentações, ateliês, conversas em grupo, propostas investigativas, estudos que associam o saber-fazer da educação infantil ao ensino superior compõem uma parte dos processos e estratégias de uma docência (para mim e para os estudantes) que se constitui a partir do reconhecimento de que a didática não é uma armadura, mas um conhecimento produtivo. Um conhecimento que, aliás, permite a invenção de uma docência que reconheça o questionamento dos porquês e, do mesmo modo, invista em como materializar no cotidiano do trabalho pedagógico operações de pensamento complexas, com estratégias, práticas e técnicas que mobilizem os sujeitos para o aprender. Não se trata, portanto, de negligenciar a didática em favor da crítica social, mas de considerar que a crítica social e a construção do conhecimento são movimentadas mais intensamente quando realizadas a partir do reconhecimento e encontro com a didática.

Já com as entranhas na didática, a minha desconstrução e reinvenção teve continuidade, paralelamente, com a atuação como coordenadora de área do Pibid ${ }^{54}$ no subprojeto Pedagogia ${ }^{55}$ (2014 a 2018). Compus o subprojeto com a intenção de mapear os temas da cultura ${ }^{56}$ que atravessavam o cotidiano dos sujeitos das escolas em que atuaríamos ${ }^{57}$. Estava acentuado o entendimento, especialmente, de que era preciso ter um conjunto de possibilidades para produzir uma docência outra. A partir de práticas pedagógicas articuladas com os temas culturais e os cruzamentos transversais entre áreas de conhecimento a pergunta sobre "como ensinar?" era tão valorizada quanto aquela sobre "por que ensinar?".

O que espero ressaltar, aqui, é o quanto a formação marcada pelos Estudos Culturais em Educação e seus atravessamentos na pedagogia e na didática foram fecundos para uma docência comprometida com análises permanentes sobre o estado da cultura; isso desde as etapas da educação básica à universidade. Afinal, trata-se de um campo de estudos que tem ajudado a formar professores e professoras que adentram o seu tempo, recolhem seus fragmentos e compreendem que analisá-lo é condição para que a escola e a docência sejam reiteradamente marcadas pela pluralidade e pelo processo de criação. A meu ver, o reconhecimento do papel constitutivo da linguagem e da cultura ${ }^{58}$, a valorização da transversalidade (noção associada ao caráter pós-disciplinar dos Estudos Culturais), o questionamento das pretensões das grandes narrativas, entre outros, criam condições para que a didática seja distanciada de intencionalidades afeitas à burocratização, prescrição e instrumentalização de caráter genérico e atemporal.

Simultaneamente, como coordenadora de área do Pibid, a função de ajudar a olhar e atuar de formas diferentes foi levada a sério. Isto é, era preciso criar mais minuciosamente, com os estudantes, o "como" se inserir na docência, o "como" organizar detalhadamente a prática docente a partir dos temas da cultura. As estratégias didáticas envolveram, desde o início, três operações principais, a saber: diagnosticar ${ }^{59}$, problematizar e transformar ${ }^{60}$. Com essas estratégias esperávamos que os bolsistas da iniciação à docência: (a) diagnosticassem os temas culturais em evidência na escola e nas aproximações com os estudantes e professores (sem recorrer, sobretudo, a um desejo de acoplar qualquer valor e juízo moral); (b) problematizassem os resultados dos diagnósticos — questionando-os — para compreenderem suas condições de possibilidade e tornarem alvo de ação docente o que foi 
diagnosticado e problematizado; (c) criassem estratégias didáticas potentes para transformar. Transformar porque assumimos a intencionalidade da pedagogia de produzir sujeitos e alterar cenários, concepções e práticas, sendo tanto saber quanto fazer. Além disso, a intenção de transformar coloca a atuação docente como eixo central que reconhece, sobretudo, a pluralidade e, por isso, investe em múltiplas estratégias de ensinoaprendizagem.

O subprojeto construiu, desse modo, um diferencial: passou a ser preciso investir em problematizar como ensinar. Por que não replicar, por exemplo, uma prática muito comum nos primeiros planejamentos — que os bolsistas de iniciação à docência construíam para serem analisados em grupo - que consistia em recorrer ao esquema básico de iniciar com um pequeno vídeo explicativo sobre um tema, depois incluir uma dinâmica de grupo (geralmente advinda da área psi) e, por fim, propor um exercício para os estudantes do ensino fundamental? Simplesmente porque com o Estudos Culturais os próprios estudantes - sejam os bolsistas universitários ou os estudantes dos anos iniciais do Ensino Fundamental que eram o foco do Pibid subprojeto Pedagogia — passaram a ser vistos como protagonistas: afinal, precisavam diagnosticar, problematizar e transformar. E, para essas operações, as estratégias docentes seriam múltiplas, mas raramente iniciadas com a lógica da explicação ou do exemplo (RANCIÈRE, 2002). Explicar e exemplificar, dentro dessa lógica, podem aparecer após algumas movimentações de pensamento que tenham acionado o aprender, mas preferivelmente não como ponto de partida, já que produzem um entorpecimento do pensar e do indagar. Pela lógica do exemplo e da explicação, o campo de possibilidades fica limitado.

Posso salientar - dentre outros aspectos que poderia abordar ainda - que hoje compreendo que para uma abertura à transformação e à docência como criação é condição que as perguntas sejam prioridade. Nesse sentido, diagnosticar e problematizar — tão próprio, sobretudo, das teorias pós-críticas - são condições de possibilidade para a produção incessante de novos modos de olhar, pensar e agir. Do mesmo modo, conjuntamente, também é condição reconhecer a produtividade da didática. Isso precisamente porque a ampliação do repertório de estratégias, técnicas e práticas contribui para que o embrutecimento do processo educacional pela explicação e pelo exemplo não seja a maior parte do que nos constitui como professores e professoras. A partir do encontro com a didática desde a formação, o campo do possível é ampliado, permitindo que, a cada problema, a experimentação e a criação sejam atreladas ao reconhecimento de que a docência implica, também, conhecer estratégias, técnicas e práticas para (re)inventá-las e, até mesmo, subvertê-las.

\section{Encontros e desencontros em torno do ensinar}

"Nada aprendemos com aquele que nos diz: faça como eu. Nossos únicos mestres são aqueles que nos dizem 'faça comigo' e que, em vez de nos 
proporem gestos a serem reproduzidos, sabem emitir signos a serem desenvolvidos no heterogêneo." (DELEUZE, Diferença e repetição, 2018, p. 43)

Como sugerem as releituras de nossas trajetórias, parece que a arte de ensinar implica no reconhecimento do inesperado. Ou seja, ensinar e aprender são searas complexas que contam, além do mais, com a presença da incerteza. Nessa direção, entendida como um tempo de experimentação, a docência acionada no saber-fazer pedagógico não lida com prescrições ou fórmulas fechadas, posto que o "como" ensinar tem relação com o contexto sociocultural e com o posicionamento dos indivíduos em torno de discursos e práticas que endereçam ao ensinar e aprender.

Nas imbricações entre educação, pedagogia e didática, assim, lidamos com uma multiplicidade de modos de se enredar em cada um desses campos. À cada escolha e posicionamento, as possibilidades se descortinam e evidenciam, sobretudo, o quanto ensinar e aprender implicam escolhas e seleções. A nosso ver, certo afastamento do pedagógico como campo estruturado por limites, com repetição de rotinas rígidas e atenção a cânones é algo produtivo para se pensar e agir. Afinal, há algumas décadas temos aprendido o quanto o mundo e os processos nele incluídos são da ordem do "[...] contingente, gratuito, disperso, instável, diverso e imprevisível" (COSTA, 2005, p. 210), sendo "[...] impossível permanecer como se está" (p. 211). Assim, também a docência é provocada a sofrer deslocamentos.

É a partir disso que olhamos para a docência, assim como para as representações acerca dos sujeitos envolvidos com o ensinar e o aprender como socialmente construídas. Se nos parece uma urgência repensar nossa docência é porque, em grande parte, as teorias pós-críticas em educação (Estudos Culturais, Filosofias da Diferença, Estudos de Gênero, etc.) fazem "[...] com que o mundo apareça aberto" (LARROSA, 2001, p. 49). Ora, dito isso, entendemos que "[...] não há uma experiência humana não mediada pela forma e a cultura é, justamente, um conjunto de esquemas de mediação, um conjunto de formas que delimitam e dão perfis às coisas, às pessoas e, inclusive, a nós mesmos" (p. 49). Como o autor segue proferindo: "A cultura, e especialmente a linguagem, é algo que faz com que o mundo esteja aberto para nós." (p. 49).

Nossa posição quanto ao ensino aparece ressignificada a partir dessa abertura ao mundo. Entrar em uma relação pedagógica implica, nesse sentido, em uma abertura a si e ao outro. O inesperado, mais uma vez, como uma condição deste tempo, aparece com a sua força. A docência é um campo de disputa em que os seus sentidos estão abertos aos processos de significação que negociamos. Ao mesmo tempo, com a docência se lida com o "outro" e com a ressonância de — em nome de uma boa e fecunda relação pedagógica fazer da atuação docente não um campo de certezas, mas da crítica e da problematização. Interessa, pois, qualificar a relação, bem como investir na problematização do saber-fazer docente. Apostamos, afinal, nos professores e professoras como sujeitos que indagam, questionam, e por isso se transformam com e a partir do conhecimento. Indagações não para reafirmar o dado, mas como abertura de espaço para o questionamento e a urgente reinvenção do conhecimento e de si mesmos. 
A atuação docente lida com a diferença, portanto. Cada estudante (mas também cada cenário, currículo, artefato, colega de instituição, etc.), por conseguinte, é uma diferença que nos olha, inquieta e, algumas vezes, perturba e/ou confronta. Acerca disso, lembramos de algo mencionado por Larrosa (2004) ao se referir a uma conversa entre amigos professores acerca de como se ocupa o lugar de professor, de "[...] como a posição do professor se constituiu reduzindo, definindo os outros pelo que não são, pelo que lhes falta, pelo que deveriam ser, o que deveriam saber, pensar, fazer" (p. 268). Nessa conversa, eles falam também da igualdade e da desigualdade na educação, de um jogo pedagógico do avançado e do atrasado, do grande e do pequeno. No texto a que nos referimos, o autor chama a atenção, no transcorrer de uma passagem muito instigante, sobre essa posição de professor, sobre a existência de duas formas de olhar para os alunos (mas não apenas para eles!), para a sala de aula, para os outros. Por um lado, há “[...] um olhar que identifica, classifica e ordena, que pretende determinar o quê de cada coisa e que se há de fazer com ela" (p. 271). Essa forma de olhar talvez não seja produtiva num tempo tão instável e em que as transformações são profundas e constantes ${ }^{61}$. De outro lado, continua Larrosa (2004, p. 271), há um outro modo de olhar, "[...] um olhar que vive, que se move, que se cruza com outros olhares, com outros corpos". Uma visão que se abre "[...] às surpresas, aos paradoxos, às aventuras, à experiência" (p. 272), algo que só ocorre quando “[...] se renuncia à vontade de saber e à vontade de poder" (p. 272). Parece que é desse segundo olhar que mais precisamos. Será que não poderíamos pensar, a partir das histórias da educação, da pedagogia e da didática, sobre as relações que temos estabelecido com esses modos de olhar?

Em outras palavras, não caberia pensar que um olhar inquieto, que se indaga, se desaloja e se transforma com o que vê poderia repercutir em nossas práticas? Nossas aproximações com a didática, expostas no decorrer deste ensaio, foram uma tentativa de visibilizar um pouco os muitos deslocamentos que se tornam possíveis ao abrirmos os modos de pensar. Ellsworth (2005), ao tratar do quanto qualquer relação pedagógica é imprevisível, nos ajuda a refletir quando questiona se, "[...] no lugar de tratar de dirigir e controlar uma relação que é incontrolável", perguntássemos "[...] que poderíamos aprender de formas de ensino que se baseiam, paradoxalmente, na impossibilidade do ensino?" (p. 18). Ao mesmo tempo em que traz essa dimensão acerca do incontrolável em nossas investidas para ensinar e aprender, a autora nos aproxima daquela "[...] abertura ao mundo", do Larrosa (2001). Ou seja, se assumirmos a imprevisibilidade de nossas investidas, de nossa docência, provavelmente ressoará o caráter experimental e criador da função docente. E isso porque qualquer atrelamento à didática não a reduziria a um "como fazer" prescritivo, mas a uma abertura à experimentação e à criação incessantes.

Considerando isso, as movimentações intelectuais em torno dos estudos pós-críticos em educação contribuem para colocarmos em suspensão o espaço e o lugar da didática. Afeitas à problematização, as teorias pós-críticas investem num gesto da docência como algo da ordem da singularidade. A docência e suas didáticas, assim, não são de qualquer tempo, mas postas em operação em cada tempo, com vínculo ao presente. Nada de 
velocidade, mas um estar atento. Nada de análises rasas e passageiras, mas de diagnósticos provisórios. Observar, pesquisar e criar como gestos, em suma, da docência.

Contudo, parece que, em embate e paralelamente com isso, ainda há uma forte ênfase nas respostas. Todas, quase sempre, tão saturadas de receitas, de formatos pré-definidos; e que numa sociedade tão cheia de transformações de todo o tipo, tão instável, não encontram, nunca, associações fixas. Essa é uma ilusão que, de certa forma, a educação e os tão fortes resquícios da modernidade nos impingem. Só que isso não dá conta dos sujeitos que encontramos. As respostas serão sempre insuficientes se não aprendermos a olhar e interrogar incessantemente, como as teorias pós-críticas em educação nos apontam.

Antonio Nóvoa (2012), em uma entrevista, nos ajuda a pensar sobre isso quando se refere ao futuro das universidades e indica três problemas centrais. De modo geral, o autor diz que o primeiro problema se relaciona à “[...] passagem de uma lógica de consumo para uma lógica de criação. $\mathrm{O}$ futuro das universidades passa pela criação, obviamente pelo lado da investigação e da ciência, mas também pelo lado da invenção, das artes, da cultura, da participação social." (p. 641-642). Defende, ainda nessa direção, que "É tempo de avançar um passo mais e de colocar a criação, nas suas mais diversas formas, no centro da vida universitária. Criação cultural. Criação científica. Criação artística. Criação de ideias e programas sociais. Criação que é inovação." (p. 642).

Compreendemos, então, o quanto a criação aparece como um substrato de qualquer possibilidade para a reafirmação da universidade (e de outras instâncias educativas, por que não?) como um tempo-espaço de criação — o que vai na contramão de qualquer expectativa de que a universidade e os professores gerenciariam formas prontas, algum conhecimento tipo fast food, porções a serem distribuídas para resolver o "como" da docência de modo padronizado. Se, por um lado, os interesses mercantis associados ao imediatismo pautam, hoje, muitas das ofertas de cursos de formação de professores, por outro lado, é no compromisso com a educação e com o pedagógico que poderíamos reafirmar a didática como aquele conjunto de conhecimentos sobre o ensinar que é da ordem da provisoriedade, posto que articulado ao papel criador das instituições educativas e de seus docentes.

Ainda, para Nóvoa (2012), o segundo problema “[...] diz respeito à forma dos estudos e à necessidade de colocar o estudo no centro da atividade universitária", o que "[...] implica uma concepção diferente da pedagogia universitária, que conduza a formas novas de trabalho: o estudo, o estudo acompanhado, a tutoria, a iniciação científica, as novas tecnologias, as redes de aprendizagem, entre outras." (p. 642). Desse modo, se há uma expectativa para que o estudo seja colocado no centro das atividades, isso sugere, ao mesmo tempo, o reconhecimento de que há muitas e díspares estratégias, técnicas e práticas para ensinar a fim de intentar atingir os sujeitos de nossas ações. Mais do que atrelar o aprender a processos amplos e generalistas, tal movimento abre espaço para a formação acompanhada e para a autoformação. Enfim, se a relação pedagógica é imprevisível, como comentamos anteriormente a partir de Ellsworth (2005), processos de formação massiva não se ajustam de forma uniforme a todos os estudantes. É preciso conduzir tal processo, 
então, com cautela, atenção e com um estar junto que processos massivos não chegam a alcançar com a desejável qualidade.

Por fim, no terceiro problema, Nóvoa (2012) se refere à necessidade de se “[...] combater o fosso entre a ciência e a universidade, eliminando a divisão entre 'ciências' e 'humanidades' ou entre investigação fundamental e aplicada." Afinal, "A ciência sem as artes, sem as humanidades, não é nada. É cega. É inútil. Transforma as sociedades do conhecimento em sociedades da ignorância. A universidade só existe se for capaz de acolher e de cultivar estas diferentes lógicas." (p. 641-642). De certo modo, esse conjunto de discussões remete, ainda, à ideia de formação cultural, da bildung alemã, que ressalta o quanto as artes, por exemplo, anexam elementos importantes em nós, em nossa formação como pessoas, na sensibilização de nosso entendimento sobre as coisas. Ou seja, a universidade como uma condição para que as diferentes áreas e campos de saber tenham o seu reconhecimento justo, sem desvalorizações desmedidas. De fato, Nóvoa (2012) formula seus comentários a partir da universidade, mas tal discussão transcende essa instituição. Ela tem a ver com nossa vida como um todo e, por isso, tem a ver com a educação, suas pedagogias e com nossas didáticas.

Ademais, com a pandemia estamos vivenciando um processo em escala global que, sobretudo, nos interroga e nos afasta das certezas. Não sabemos que tipo de futuro se desenhará e qualquer resposta advém da provisoriedade. Mais uma vez, a humanidade é posta diante da urgência da criação, do estudo e da transversalidade das áreas. Ao mesmo tempo, nossas instituições educativas — assim como outras esferas sociais - têm feito intensos movimentos em torno do que, por que e como ensinar e aprender. A didática, assim, tem sido recorrentemente acionada para que, no interior de escolhas e seleções docentes, seja compartilhado como o ensino tem acontecido sob as condições adversas da pandemia. Socializações de práticas, reflexões sobre o futuro das instituições e sobre os usos múltiplos das tecnologias digitais e diferentes plataformas têm sido alvos importantes de incessantes discussões e diálogos. O ofício docente, de tal modo, tem aguçado a sua face didática, inventando possibilidades para operar a partir das condições específicas deste espaço-tempo.

Importante registrarmos, por fim, que hoje percebemos ter sido um salto colocar $A$ Didática em Questão, no Brasil. O Movimento manteve aberta a discussão, conservando as didáticas sob permanente escrutínio, persistindo nos questionamentos sobre para que servem, quando servem, como se transformam, o que produzem, como, quando e para que. Nessa direção, consideramos que importa a didática continuar em questão, se isso significar manter-se viva a atuação com ela e sobre ela, bem como o desejo de permanentemente perguntar o que se está fazendo nela, com ela, sobre ela. Tudo isso, sintomas da edificante conduta de manter a preocupação com o ensinar e aprender sempre presentes em nossas agendas educativas e educacionais. 


\section{Notas}

1. As autoras agradecem as considerações, críticas e sugestões formuladas pelas colegas professoras $\mathrm{Dr}^{\mathrm{a}}$ Beatriz Fischer e Dr $^{a}$ Mônica Knöpker, que se dispuseram generosamente a ler versões deste ensaio. Suas contribuições foram inestimáveis.

2. Referimo-nos a teorias educacionais e educativas considerando que as primeiras seriam as que se referem, predominantemente, a questões macro da educação, enquanto as do segundo grupo estariam voltadas especialmente aos processos pedagógicos micro. Concordamos, contudo, tratar-se de uma distinção pouco rígida, que utilizamos inspiradas em nossas vivências na educação. Ela não é, necessariamente, adotada pela comunidade da área, sendo os termos, frequentemente, empregados indistintamente.

3. As traduções do espanhol são de nossa autoria.

4. Neste ensaio, intentamos distinguir a didática entendida como "arte de ensinar" da Didática como disciplina acadêmica. Quando nos referimos ao primeiro caso, grafamos a palavra com inicial minúscula; quando se trata do segundo, usamos inicial maiúscula. Reconhecemos, contudo, que há passagens em que essa diferenciação é difícil e discutível.

5. Trata-se da disseminação mundial do Coronavírus (SARS-CoV-2) que provoca a doença infecciosa (síndrome respiratória aguda) nomeada COVID 19, declarada pandemia pela Organização Mundial da Saúde (OMS) a partir de março de 2020.

6. Compartilhamos o entendimento de que "É fácil fazer corresponder a cada sociedade certos tipos de máquina, não porque as máquinas sejam determinantes, mas porque elas exprimem as formas sociais capazes de lhes darem nascimento e utilizá-las" (DELEUZE, 1992, p.223). Nesse sentido, a nossa referência aos aparatos tecnológicos se deve na medida em que eles "exprimem as formas sociais" que, em cada espaço-tempo, são mais proeminentes. O ensino, sendo fruto de práticas sociais continuamente em ação e transformação, também é convocado a ser repensado frente a um cenário em que as tecnologias tem sido centrais.

7. Trata-se do Instituto de Filosofia e Ciências Humanas da Universidade Federal do Rio Grande do Sul (IFCH/UFRGS).

8. A criação do Centro Universitário Experimental de Vincennes, ou Universidade de Paris VIII, no verão de 1968, na França, expressou o desejo de inventar novos formatos de ensino na educação universitária europeia. Ver a esse respeito o artigo de Ramos do Ó (2019), cf. ref. bibliog.

9. Realizado na Faculdade de Educação da UFRGS.

10. Evento realizado na Pontifícia Universidade Católica do Rio de Janeiro (PUC-RIO) em 2012.

11. Atuando como professora e pesquisadora no Departamento de Ensino e Currículo da Faculdade de Educação da UFRGS (FACED/UFRGS).

12. A quem agradeço, mais uma vez, a honra daquele convite. Preparar-me para aquela participação, além de fazer com que eu revisitasse minha trajetória acadêmica, propiciou que eu introduzisse a didática no conjunto de meus interesses teóricos e de pesquisa mais recentes.

13. A esse respeito, ver o artigo de Wortmann, Costa e Silveira (2015), cf. ref. bibliog.

14. Troquei muitas ideias com meu grupo de pesquisa, considerei resultados de nossas investigações, assim como as reflexões que eu vinha realizando nos últimos anos sobre cultura e pedagogia e sobre as relações entre escola $e$ cultura contemporânea. Busquei documentos e publicações sobre a didática e sobre o Movimento A Didática em Questão, ouvi colegas e colhi dados sobre as transformações da Didática no Departamento de Ensino e Currículo da UFRGS, onde atuei por muitos anos. Além dessas buscas, fui também assistir a apresentação de alguns trabalhos no GT Didática da Associação Nacional de Pós-Graduação e Pesquisa em Educação (Anped) durante a $35^{\text {a }}$ Reunião Anual, realizada em outubro de 2012, no município de Porto de Galinhas/PE.

15. Realizada no IFCH/UFRGS.

16. Colégio de Aplicação da UFRGS, onde se realizavam os estágios de alunos das licenciaturas da Universidade.

17. Oferecida na FACED/UFRGS.

18. O currículo da licenciatura em Filosofia que cursei permitia registro no MEC também em Psicologia e Sociologia.

19. Curso Normal do Colégio Sevigné e Curso de Educação Familiar na Escola de Educação Familiar Maria Adelaide, ambas em Porto Alegre. 
20. As faculdades de Educação começavam a ser criadas no País, justamente para imprimir uma dimensão mais especializada e técnica ao ensino. A Faculdade de Educação da UFRGS foi uma das primeiras, em 1970, tendo se constituído a partir do desmembramento do Departamento de Educação da Faculdade de Filosofia.

21. GV (grupo de verbalização) e GO (grupo de observação). Nessa técnica, o GV discute inicialmente um tema e o GO observa. A seguir os papéis se invertem.

22. Também conhecido como brainstorming, é uma técnica que visa ao compartilhamento dinâmico de ideias. A partir disso, ideias iniciais sobre um assunto podem ser levantadas, soluções para um problema específico podem ser encontradas, entre outras opções.

23. Trata-se de uma técnica em que os estudantes são divididos em pares para discutir sobre uma questão ou problema. Simultaneamente, assim, toda turma trabalha sobre um mesmo foco e, após, acontece a socialização das conversas.

24. Lembro de um pequeno livro de Celso Antunes, indicado por uma colega, contendo uma coleção de técnicas de dinâmica de grupo a serem tiradas da cartola nas emergências!

25. Minha ex-supervisora de estágio na licenciatura em Filosofia, coordenadora da Divisão de Filosofia do CA, assim como dos cursos do PREMEN que formavam os especialistas em educação para essas escolas, e que mais tarde veio a se tornar minha orientadora de doutorado.

26. Programa de Expansão e Melhoria do Ensino.

27. Oferecido pela Pontifícia Universidade Católica do Rio Grande do Sul (PUCRS).

28. Equipe composta por docentes que ministravam a disciplina em três universidades - UFRGS, PUCRS e UNISINOS.

29. A referência da obra é: JARDIM, Ilza et al. Estrutura e Funcionamento do Ensino de $\mathbf{1}^{\mathbf{0}}$ e $\mathbf{2}^{\mathbf{0}}$ Graus. 1 Ed. Porto Alegre: Sagra, 1973. Éramos 8 co-autoras, foram publicadas mais de 20 edições, sendo o Manual indicado inclusive em cursos de preparação para concursos do magistério em muitos estados e municípios do País.

30. Realizada mediante coleta de dados por questionários respondidos por iniciantes e concluintes dos cursos das várias Licenciaturas em uma amostra que abrangeu mais de 500 estudantes.

31. Trata-se do SEDIPE da PUCRS.

32. UFRGS - Departamento de Ensino e Currículo da Faculdade de Educação (DEC/FACED/UFRGS).

33. Ver a esse respeito o artigo Camozzato e Costa (2013), cf. ref. bibliog.

34. Encontro Nacional de Didática e Prática de Ensino.

35. Eu mesma fiz parte do GTL/UFRGS - junto com uma professora do IFCH/UFRGS, para pesquisar a formação de professores de Filosofia, produzindo um imenso relatório [aproximadamente 600 p.], cujo destino e utilização, hoje, desconheço.

36. Disponível em: http://escolanomade.org/wp-content/downloads/deleuze-o-abecedario.pdf. Acesso em: 15 jun. 2020.

37. Realizada no Programa de Pós-Graduação em Educação da UFRGS.

38. Minha aproximação com estudos sobre "trabalho docente" deu-se quando, durante o doutorado, fui contemplada com uma bolsa do British Council para fazer um curso na Universidade de East Anglia, em Norwich, na Inglaterra. O foco eram os Teacher's Centres, uma modalidade de educação continuada de professores adotada naquele país. Naquele curso, do qual participavam professores de vários países, discutiu-se muito a pesquisa-ação como modo de investigação em que os próprios professores realizam a análise de seu trabalho como docentes.

39. Algumas dessas obras são Lawn e Ozga (1988) e Lawn e Grace (1990), cf. ref. bibliog.

40. Ingressei na Universidade Luterana do Brasil para atuar como professora de Graduação e no Programa de PósGraduação em Educação.

41. Devido a atividades de pesquisa e avaliação que realizei, na época, pude constatar tal condição em boa parte das universidades privadas, assim como em algumas públicas.

42. Na teoria de aprendizagem de David Ausubel são nomeados subsunçores, referindo-se aos conhecimentos que os estudantes já têm, a chave que os conectará a novas aprendizagens com sentido.

43. Ver entrevista de Umberto Eco a Lila Azam Zanganeh em http://www.theparisreview.org/interviews/5856/the-art-offiction-no-197-pauleacute-baacutertoacuten

44. Formulação original atribuída ao filósofo alemão Ludwig Wittgenstein.

45. Informações sobre estes e outros filmes podem ser encontradas na internet. 
46. A professora Rosália Duarte, da PUC-RIO, tem sido uma das batalhadoras nesta cruzada para introduzir filmes na sala de aula com objetivos pedagógicos e não para substituir professor ausente ou acalmar as turmas em dias de chuva!

47. Universidade Estadual do Rio Grande do Sul (UERGS), unidade do município de Bagé.

48. Realizados na UFRGS

49. Refere-se a uma disciplina de caráter teórico-prático que, em 2014, com o novo Projeto Político-Pedagógico (PPC) do Curso, passou a denominar-se Ensino Médio: Docência e processos pedagógicos. A intenção principal é proporcionar aos estudantes de Pedagogia uma formação voltada à docência no ensino médio, com especial acento nas matérias pedagógicas.

50. De forma sucinta, é possível assinalar que as teorias críticas em educação a veem como um ato político em torno de questões articuladas ao poder, ideologia, reprodução social e cultural, hegemonia, classe social, estrutura econômica. Ademais, a entendem como abertura para a conscientização, emancipação e libertação dos indivíduos.

51. Nas teorias pós-críticas, por sua vez, há um alargamento da noção de política. Ela passa a ser compreendida, sobretudo, para além de um eixo estrutural, visto que sua capilaridade ganha as feições de uma micropolítica praticada em diferentes espaços e relações. Questões relacionadas aos embates em torno da produção de subjetividades, identidades, diferenças, assim como discussões em torno da representação, cultura, etnia, gênero, sexualidade, saberpoder, discurso e processos de significação ganham primazia, dentre outros pontos.

52. Trata-se de teorias comumente atreladas a um processo de despolitização social. Ao contrário das teorias críticas e pós-críticas, abdicariam da investigação das relações de saber-poder e agiriam em torno de uma suposta neutralidade almejada - sendo este um dos grandes pontos de sua contestação na esfera educacional. Suas intencionalidades teriam como foco processos de ensinar e aprender a partir da valorização da didática, da organização e do planejamento dos processos educacionais incluindo, ainda, preocupações em torno de objetivos, eficiência dos processos, dentre outros pontos.

53. Refere-se a um espaço organizado para incitar o desejo de criação, experimentação e manipulação. Nos ateliês, o foco está na experiência a partir de múltiplos materiais disponibilizados pelo professor ou, inclusive, com a contribuição dos estudantes.

54. Programa Institucional de Bolsa de Iniciação à Docência, que integra a Política Nacional de Formação de Professores do Ministério da Educação (MEC). O Pibid surgiu em 2007 com o objetivo de propiciar aos estudantes da primeira metade de cursos de licenciatura uma aproximação com o cotidiano de escolas públicas de nosso país. O Pibid segue ativo, apesar de alterações significativas no tempo de duração dos editais, entre outros aspectos.

55. No decorrer do subprojeto recolhemos muitos depoimentos, cartas e outros registros que indicam a produtividade do trabalho pedagógico realizado. Os artigos a seguir sinalizam isso: Camozzato e Mattia (2016); Martinez e Camozzato (2017), cf. ref. bibliog.

56. Os quais incitam a uma inesgotável articulação com questões centrais nas sociedades de hoje. Nessa direção, trabalhar com temas da cultura permite a operação de estar atento à nossa contemporaneidade para colocá-la em questão, indagá-la, e não a naturalizar.

57. Foram 3 diferentes escolas, com 24 bolsistas de iniciação à docência, 3 professores supervisores e, junto comigo, mais uma colega de universidade como coordenadora de área.

58. A respeito do papel instituinte e constituinte da cultura e da linguagem tem sido central o artigo de Stuart Hall (1997) intitulado A centralidade da cultura: notas sobre as revoluções culturais do nosso tempo.

59. Aqui a opção por nomear a operação como diagnosticar advém das discussões de Artières (2004), que mostra o quanto Michel Foucault foi um diagnosticador do presente. Ou seja, alguém que — a partir da filosofia — pretendia tornar visível o que está ligado a nós e que compõe o nosso tempo presente, num processo de "[...] diagnosticar as forças que constituem nossa atualidade e que ainda a movimentam." (ARTIÈRES, 2004, p. 18).

60. O uso da noção de transformar, em tal contexto, não tem qualquer pretensão de assentar as bases para uma mudança radical a partir de um engajamento às noções caras ao discurso educacional crítico, por exemplo. Quando optamos, no Pibid, por utilizar o termo foi apenas para dar destaque ao protagonismo dos docentes de, após diagnosticar e problematizar, assumir - humildemente — que parte de sua função é lidar com os efeitos dos saberes e das práticas postos em operação a partir das micropolíticas do fazer docente.

61. Essa instabilidade do nosso tempo tem sido amplamente abordada por pensadores contemporâneos, especialmente por Zygmunt Bauman ao se utilizar da metáfora da liquidez. 


\section{Referências}

ANASTASIOU, Léa das Graças Camargos; ALVES, Leonir Pessate (Orgs.). Processos de Ensinagem na Universidade. Pressupostos para as estratégias de trabalho em aula. Joinvilie, SC: Editora Univille, 2004.

ARTIÈRES, Philippe. Dizer a atualidade: o trabalho de diagnóstico em Michel Foucault. In: GROS, Frédéric (Org.). Foucault: a coragem da verdade. Trad. Marcos Marcionilo. São Paulo: Parábola Editorial, 2004. p. 15-37.

CAMBI, Franco. História da pedagogia. Trad. Álvaro Lorencini. São Paulo: Fundação Editora UNESP, 1999.

CAMOZZATO, Viviane Castro; COSTA, Marisa Vorraber. Vontade de pedagogia — pluralização das pedagogias e condução de sujeitos. Cadernos de Educação da UFPel, n.44, jan-abr. 2013.

CAMOZZATO, Viviane Castro; MATTIA, Jaqueline Lidório de. A cultura contemporânea na escola: oportunidade para (re)pensar sobre saberes, formações e aprendizagens. In: HOPPE, Martha Marlene Wankler; LEMOS, Sandra Monteiro (Orgs.). A construção do Pibid-Uergs: experiências de gestão compartilhada entre universidade, escolas e comunidades. São Leopoldo: Oikos, 2016. p. 131-144.

CANDAU, Vera Maria (Org.). Rumo a uma nova didática. Petrópolis: Vozes, 1988.

COSTA, Marisa Vorraber. Gênero, classe e profissionalismo no trabalho de professoras e professores de classes populares. (Tese de doutorado). Porto Alegre: PPGEDU/UFRGS, 1995.

COSTA, Marisa Vorraber. Velhos temas, novos problemas - a arte de perguntar em tempos pós-modernos. In: COSTA, Marisa Vorraber; BUJES, Maria Isabel Edelweiss (Orgs.). Caminhos investigativos III: riscos e possibilidades de pesquisar nas fronteiras. Rio de Janeiro: DP\&A, 2005. p. 199-214.

CUNHA, Marcus Vinícius da. John Dewey: uma filosofia para educadores em sala de aula. Petrópolis: Vozes, 1994.

DELEUZE, Gilles. Conversações. Trad. Peter Paul Pélbart. São Paulo: Ed. 34, 1992.

DELEUZE, Gilles. Diferença e repetição. Trad. Luiz Orlandi e Roberto Machado. Rio de Janeiro/São Paulo: Paz e Terra, 2018.

ELLSWORTH, Elizabeth. Posiciones em la enseñanza: diferencia, pedagogía y el poder de la direccionalidad. Trad. de Laura Trafí Prats. Madrid: Akal, 2005.

FABRE, Michel. Existem saberes pedagógicos? In: HOUSSAYE, Jean et al. Manifesto a favor dos pedagogos. Trad. V. Dresch. Porto Alegre: Artmed, 2004. p. 97-120.

FOUCAULT, Michel. Aula de 7 de janeiro de 1976. In: FOUCAULT, Michel. Em defesa da sociedade: curso no Collège de France (1975-1976). Trad. Maria Ermantina Galvão. São Paulo: Martins Fontes, 1999. p. 03-26.

GASPARIN, João Luiz. Comênio ou da arte universal de ensinar tudo a todos. São Paulo: Papirus, 1994.

GIL, Antonio Carlos. Metodologia do Ensino Superior. São Paulo: Atlas, 2005.

GRILlO, Marlene et al. (Org.). A gestão da aula universitária na PUCRS. Porto Alegre: EDIPUCRS, 2008.

HALL, Stuart. A centralidade da cultura: notas sobre as revoluções culturais do nosso tempo. Educação \& Realidade, v. 22, n.2, jul./dez., 1997.

HOUSSAYE, Jean. Pedagogia: justiça para uma causa perdida? In: HOUSSAYE, Jean et al. Manifesto a favor dos pedagogos. Trad. V. Dresch, Porto Alegre: Artmed, 2004. p. 09-45.

LARSON, Magali Sarfatti. The Rise of Professionalism: a Sociological Analysis. [s.1.]: University of California Press, 1977.

LARROSA, Jorge. Pedagogia profana. Trad. Alfredo Veiga-Neto. Belo Horizonte: Autêntica, 2001. 
LARROSA, Jorge. Educação e diminuição. In: LARROSA, Jorge. Linguagem e educação depois de Babel. Trad. Cynthia Farina. Belo Horizonte: Autêntica, 2004. p. 265-294.

LAWN, Martin; OZGA, Jennifer. The educational worker? Reassessment of teachers. In: OZGA, J. (Ed.) Schoolwork, Approaches to the labour process of teaching. London: Open University Press, Milton Keynes, 1988.

LAWN, Martin; GRACE, Gerald. Teachers: the culture and politics of work. Sussex: The Falmer Press, 1990.

LIBÂNEO, José Carlos. Democratização da escola pública — A pedagogia crítico-social dos conteúdos. São Paulo: Cortez Editora, 1987.

LUZURIAGA, Lorenzo. Pedagogia. Trad. Lólio Lourenço de Oliveira e J. B. DamascoPenna. 3ed. São Paulo: Companhia Editora Nacional, 1961.

MARTINEZ, Raquel Vieira; CAMOZZATO, Viviane Castro. Experiência e iniciação à docência: daquilo que nos passa, nos acontece. In: LEMOS, Sandra Monteiro; AZEVEDO, Gilmar de (Orgs.). Os impactos do Pibid na iniciação à docência na UERGS. Porto Alegre: Evangraf, 2017. p. 85-104.

MARTINS, Pura Lúcia Oliver. Didática Teórica/Didática Prática: para além do confronto. São Paulo: Loyola, 1989.

MASETTO, Marcos Tarciso. Competência pedagógica do professor universitário. São Paulo: Summus, 2003.

NARODOWSKI, Mariano. Comenius \& a Educação. Trad. Alfredo Veiga-Neto. Belo Horizonte: Autêntica, 2001.

NÓVOA, António. Le Temps des Professeurs. Lisboa: Instituto Nacional de Investigação Científica, 1987.

NÓVOA, António. Entrevista a Lucíola Licínio C.P. Santos. Educação \& Sociedade, vol. 33, n. 119. Campinas, abr-jun. 2012.

PLANCHARD, Émile. Introdução à pedagogia. Coimbra: Coimbra editora, 1962.

RANCIÈRE, Jacques. O mestre ignorante: cinco lições sobre a emancipação intelectual. Trad. Lílian do Valle. Belo Horizonte: Autêntica, 2002.

RAMOS do Ó, Jorge. Ouvir falar o pensamento, aprender a falar o pensamento no interior da universidade: o testemunho dos "professores" Michel Certeau, Gilles Deleuze, Michel Foucault e Roland Barthes. Revista Brasileira de Educação, v. 24, e240021, 2019.

WORTMANN, Maria Lúcia; COSTA, Marisa Vorraber; SILVEIRA, Rosa Hessel. Sobre a emergência e a expansão dos Estudos Culturais em Educação no Brasil. Educação, PUCRS, Porto Alegre, v. 38, n. 1, jan./abr. 2015.

ZABALA, Antoni. A prática educativa: como ensinar. Trad. Ernani F. da F. Rosa. Porto Alegre: Artmed, 1998.

ZULUAGA, Olga et al. Pedagogía y epistemología. Bogotá: Magisterio editorial, 2011a.

ZULUAGA, Olga et al. Educación y pedagogia: uma diferencia necessária. In: ZULUAGA, Olga et al. Pedagogía y epistemología. Bogotá: Magisterio editorial, 2011b. p. 21-40.

\section{Correspondência}

Marisa Vorraber Costa: Licenciada em Filosofia, Mestre em Educação e Doutora em Ciências Humanas Educação, com estágios de pós-doutorado em universidades de Portugal, Espanha e Alemanha. Professora Titular em Ensino e Currículo da UFRGS (aposentada). Consultora do Núcleo de Estudos sobre Currículo, Cultura e Sociedade (NECCSO/UFRGS). 


\section{E-mail: vorrabercosta@gmail.com}

Viviane Castro Camozzato: Pedagoga, mestre e doutora em Educação pela UFRGS. Professora adjunta da Universidade Estadual do Rio Grande do Sul (Uergs).

E-mail: vicamozzato@gmail.com

Texto publicado em Currículo sem Fronteiras com autorização das autoras 